\title{
壁型枠への高流動コンクリート打設の流動シミュレーション FLOW SIMULATION OF HIGH-FLUIDITY CONCRETE INTO WALL TYPE FORM
}

\author{
石黒和 浩*, 森 博嗣**, 富谷潤一***, 上杉誠一**** \\ Kazuhiro ISHIGURO, Hiroshi MORI, Junichi TOMITANI \\ and Seiichi UESUGI
}

In this paper, the high-fluidity concrete placing into the wall form with the obstructions is simulated in order to confirm that this 3-D flow simulation system can be applied to full-sized structure. In the beginning, the parametric studies are carried out about the handling between the form and fresh concrete on the touching side, and the rheology constants on the fluid surface are examined. As a result, the experiment is simulated by correcting the rheology constant of the surface material, multiplying the rate of VOF(volume of fluid) and decreasing to $1 / 2$. Next, the parametric studies are executed about the rheology constants and the amount of obstructions in the wall form by this decrease method. As a result, it is clarified that this 3-D flow simulation system can correctly express the influence by the rheology constants and the amount of obstructions.

Keyword: flow simulation, high-fluidity concrete, fresh concrete, rheology, wall type form 流動シミュレーション, 高流動コンクリート, フレッシュコンクリート, レオロジー, 壁型枠

1. はじめに

フレッシュコンクリートの流動挙動をシミュレーションによって

事前に予測することにより、適切な打設や締固めの方法を計画するこ とが可能となり、コンクリート工事における施工の合理化・省力化を 実現できる。特に、締固めを行わない高流動コンクリートを用いる施 エにおいては、コンクリートの立填状況を予測することが非常に重要 になるため、各施工条件に合わせたコンクリートの品質設定や打設計 画の事前検討を行ううえで、流動シミュレーション技術の確立が求め られている。

フレッシュコンクリートの流動シミュレーションを行うためには、 入力値となる力学特性の定量化と、流動解析手法の検討が必要となる。 力学特性の定量化においては、フレッシュコンクリートのレオロジー 特性をビンガムモデルにより表現し、降伏值と塑性粘度を測定する研

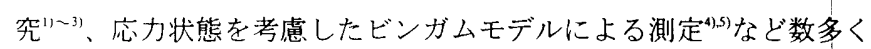
の成果が報告されている。一方、フレッシュコンクリートの流動解析 手法については、理論式を展開して举動を解明する理論的手法(6や数 値計算を用いる解析的手法フ99等が举げられ、スランプ試験や管内流 動を対象とした研究が報告されている。しかし、いまだ解析例は少な く、その多くはコンシステンシ一試験や小規模の型枠を対象とした2 次元解析であり、実際の施工規模のものや壁状の構造物などにおいて
3 次元的影響を考慮した例はほとんどみられない。

著者らは、これまでニュートンモデルおよび非ニュートンモデルを 対象とした 3 次元熱流体解析プログラム ${ }^{10)}$ を拡張して、ビンガムモデル の解析が可能な流動シュミレーションシステムを開発し、スランブ試 験の2次元流動シミュレーションを行った"1。

本研究は、開発した流動シミュレーションシステムの実施工八の適 用性を検討するため、壁状の型伜に障害物がある場合の全体的な流動 現象を対象とした3次元流動シミュレーションを行った。最初に境界 部分（型枠と接する位置のフレッシュコンクリート）の取扱い方法を 決定するために、標準的な流動性能を持つ高流動コンクリートを対象 とした解析結果と、同様の条件で行った実験結果 ${ }^{12), 13)}$ との比較・検討 を行った。続いて、検討結果により決定した境界部のモデルを用いて、 フレッシュコンクリートのレオロジ一定数と壁型枠中に配置する障 害物量をパラメータとした解析を行った。実験結果との比較・検討に より、本流動シミュレーションシステムの実規模の3次元举動に対す る適用性について報告する。

\section{2. 解析方法}

2.1 解析手法

フレッシュコンクリートは、セメントペーストと骨材より成る複合
* 安藤建設(制技術研究所 研究員

** 名古屋大学大学院工学研究科建築学専攻 助教授・工博

***安藤建設侏建築本部技術部

***** 棒ソフトウェアクレイドル
Research Engineer, Research Center, Ando Corporation

Assoc. Prof., Dept. of Architecture, Graduate School of Engineering, Nagoya Univ., Dr. Eng.

Ando Corporation

Sóftware Cradle Co., Ltd. 
材料と言えるが、流動中の性状と挙動から、連続体の流動現象として の取り扱いが可能と判断し、著者らが開発した3次元熱流体解析プロ グラムにより解析を行った。なお、高密度に配筋された部分をフレッ シュコンクリートが通過する際には、粗骨材とモルタルマトリックス つ相対移動が生じ、連続体としての取扱いが難しくなるが、鉄筋の近 傍に㧍けるレオロジ一性質を変化させることにより、全体的な流動性 状を近似的に表現することが可能であると考えられる。また、レオロ ジー的性質の変化割合や影響範囲は、フレッシュコンクリートを粗骨 材とモルタルに分離してモデル化し、鉄筋近傍の挙動を解析すること によって求められるものと思われる。ただし、本研究では、壁状構造 物における境界面の3次元的影響についてのみ検討することとした。 本手法は、数值解析手法の一つであるコントロールボリューム法を用 いている。

解析ブログラムにおいて扱っている基本方程式は、流動解析に関す るもりと、自由表面のアルゴリズムに関するものがある。流動解析に 拐ける基本方程式とは、式(1)に示寸 Navier-Stokes の運動方程式と、 式(2)に示寸流体質量の保存式である。

$$
\left.\begin{array}{c}
\rho \frac{\partial u}{\partial t}=\rho X-\frac{\partial p}{\partial x}+\eta \nabla^{2} u \\
\rho \frac{\partial v}{\partial t}=\rho Y-\frac{\partial p}{\partial y}+\eta \nabla^{2} v \\
\rho \frac{\partial w}{\partial t}=\rho Z-\frac{\partial p}{\partial z}+\eta \nabla^{2} w \\
\nabla^{2}=\frac{\partial^{2}}{\partial x^{2}}+\frac{\partial^{2}}{\partial y^{2}}+\frac{\partial^{2}}{\partial z^{2}}
\end{array}\right\}
$$

表面形状が重要な問題を扱う場合、自由表面を含む流動解析を行う 必要がある。自由表面の評価方法としては、(1)SURF、(2)MAC、(3)ALE、 (4)VOF が举げられ、本解析プログラムでは、その代表的モデルであ るVOF 法を採用した。VOF（Volume of Fluid）法は、流動現象を解析 寸るための解析領域内流体要素に、その要素内に流体が占める流体体 積の比率（流体体積率 VOF）を定義し、移流計算によって、変化す る自由表面を求めるものである。また、VOF 値は $0.0 \leqq V O F \leqq 1.0 の$ 範 囲 $(\mathrm{VOF}=0.0$ : 気相, $\mathrm{VOF}=1.0$ : 液相, $0.0<\mathrm{VOF}<1.0$ : 表面要素) で あり、各要素の VOF 值が決まれば、表面要素が決定され、表面形状 が定まる。また、VOF 関数の時刻および空間での変化は、保存則を 示寸式(3)を離散化し、数值計算することによって求められる。

$$
\frac{\partial V O F}{\partial t}+\frac{\partial V O F * u}{\partial X}+\frac{\partial V O F * v}{\partial Y}+\frac{\partial V O F * w}{\partial Z}=0
$$

ここに、VOF:VOF値

なお、解析における外力条件として、重力加速度を作用させ、また 流体（フレッシュコンクリート）は非圧縮として取り扱った。

\section{2 降伏関数}

フレッシュコンクリートの降伏関数については、降伏值 $\tau \mathrm{y}$ を持つ ビンガムモデルで表されると考えられる。本解析プログラムでは、基 本的にはニュートンモデルおよび非ニュートンモデルの使用を想定
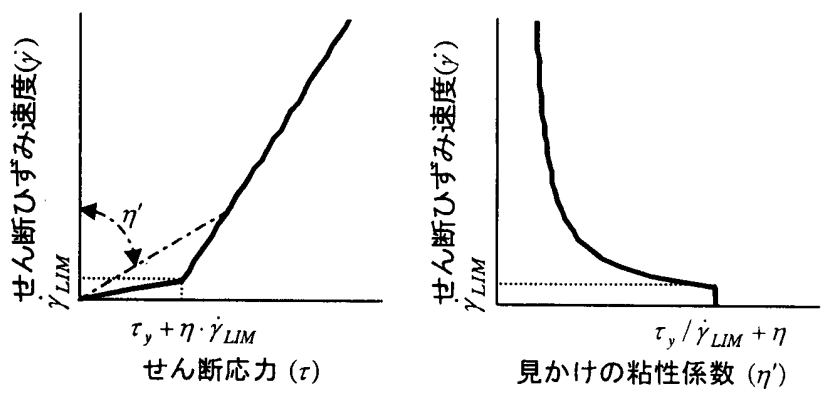

図 1 見かけの粘性係数を使用した降伏関数

しているため、ビンガムモデルの降伏関数を使用するためには見かけ の粘性係数 n’を与えて表現する必要がある。ビンガムモデルの降伏 関数を式(4)に、見かけの粘性係数使用の降伏関数を式(5)に示寸。

ビンガムモデルの降伏関数

$$
\tau=\eta \cdot \dot{\gamma}+\tau_{y}
$$

見かけの粘性係数使用の降伏関数

$$
\begin{aligned}
& \tau=\eta^{\prime} \cdot \dot{\gamma} \\
& \dot{\gamma}>\dot{\gamma}_{L I M} \rightarrow \eta^{\prime}=\frac{\tau_{y}}{\dot{\gamma}}+\eta \\
& \dot{\gamma}<\dot{\gamma}_{L I M} \rightarrow \eta^{\prime}=\frac{\tau_{y}}{\dot{\gamma}_{L I M}}+\eta \\
& \beth こ に 、 \tau: \text { せん断応力 } \\
& \eta: \text { 塑性粘度 } \\
& \dot{\gamma}: \text { せん断ひずみ速度 } \\
& \tau_{y}: \text { 降伏值 } \\
& \eta^{\prime}: \text { 見かけの粘性係数 } \\
& \dot{\gamma}_{L I M} \text { : 定数 }
\end{aligned}
$$

通常、ビンガム流体の降伏関数では、塑性粘度 $\eta$ は一定値として扱

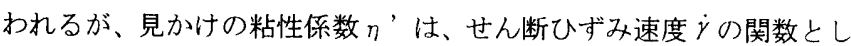
て定義される。これにより、ニュートンモデルの降伏関数を用いてビ ンガムモデルの降伏関数を近似する。見かけの粘性係数り’を使用す る降伏関数を図1に示す。せん断ひずみ速度 $\dot{\gamma}$ が限りなく0に近づくと 見かけの粘性係数 n’は発散するため限界值 $\dot{\gamma}$ LIM を設けて解析を行 った。なお、 $\dot{\gamma}$ LIM の值により、解析に用いる最大の見かけの粘性倸 数が変化するため、解析結果に影響する。 $\dot{\gamma}_{\text {LIM }}$ をバラメータとした 事前検即を行い、本解析で対象とする高流動コンクリートにおいて解 析結果に大きな影響を与えなかった $\dot{\gamma}$ LIM=1.0E-3(1/s)を用いること とした。

\section{3 境界条件}

流体（フレッシュコンクリート）と固体（型枠，障害物）間の境界 条件は、流体と固体間には滑りがないものとし、境界面の応力条件は 速度分布に比例するものとした。

\section{3. 境界部分の低減方法に関する予備解析}

壁状の型枠中を流れるフレッシュコンクリートの流動現象をシミ ユレートするにあたり、最初に2次元解析を行った。その結果、2次元 解析によって実験結果をシミュレート寸るためには、フレッシュコン クリートのレオロジー定数を3倍程度に増加させる必要があっだ、2 次元解析では、壁状の型枠において最も面積が大きい前後の型枠面に 接する境界（以降、単に前後の型枠面と呼ぶ）が考慮されないため、 レオロジー定数を大きくする必要があったと考えられる。したがって、 
正確なレオロジー定数を用いて壁状の型枠をシミュレートするため には、3次元解析を行う必要があると判断された。

一方、3次元解析を行った結果、逆にレオロジ一定数を $1 / 2$ 以下に低 減する必要があっだ!。壁の厚み方向の要素分割数が少ないため、境 界面からの影響による速度分布が粗くなり、境界の影響を過大に評価 寸る可能性を㗭念して、分割数によるパラメトリックスタディを行っ た。しかし、分割数を2,3,4,5と変えても流動形状の違いはほとんど 現れなかった。

実際のコンクリートが型枠中を流動する場合、型枠面に噴霧された 水の上を滑るような現象や、型枠面でペースト分が分離して境界層と なるような現象が観察される。解析上では、コンクリートを均質体と 捉え単一のレオロジー定数を与えて評価しているが、境界面では異な ったレオロジ一定数使用の必要性を示唆すると考えられる。

以上の考虑を踏まえて、本研究では、解析に用いるコンクリート全 体のレオロジ一定数を変化させるのではなく、境界部分のみのそれを 低減する方法について以下に検討を行う。

\section{1 解析モデル}

検討に用いた解析モデルを図2に示す。壁状の型枠を想定し、型枠 中には直方体の障害物を配置し、壁の厚み方向（Y 方向の中心）で対 称モデルとした。コンクリートの打設は、実験と同様にロートのモデ ル化を行い、その上面に連続流入流出境界を設けて、先端には流速規 定により一定流速を与えた。解析領域内（壁型伜およびロート）の $\mathrm{XZ}$ 平面のメッシュ分割は $10 \mathrm{~mm}$ ピッチとした。Y 方向メッシュ分割 林、ハラメトリックスタディにおいて2分割では解析が不安定であっ たため3分割とし、型枠近傍の境界付近で速度勾配が大きく、中央で は勾配がなくなる栓流の速度分布を示すことを考慮して、中央部から 30、10、10mm の分割とした。また、図中に(1)〜 (4)で示した障害物間 中央位置の試料上昇高さを10秒毎にプロットし、この值を用いて解析 結果の評価を行った。

\section{2 境界部分の低減}

境界部のレオロジ一定数の低減を行う範囲は、固体（型枠）表面上 り1要素（厚さ $10 \mathrm{~mm}$ ）とした。実際に流動している状態における境界 部分のレオロジー定数を測定することは難しいため、表1に示す各種 低減条件で解析を行い、その結果を実験結果と比較して、最適な低減 条件を絞り込むこととした。ひずみ速度 $\dot{\gamma}$ に対応する見かけの粘性係 数 $\eta ’$ を1/1 1/10に低减した。また、垂直応力の増加にともないせん 断抵抗力が増加するとの研究結果 ${ }^{4}$ 考慮して、コンクリート自重に よる垂直応力が作用する型枠底面扝よび障害物上面の低減率を他の

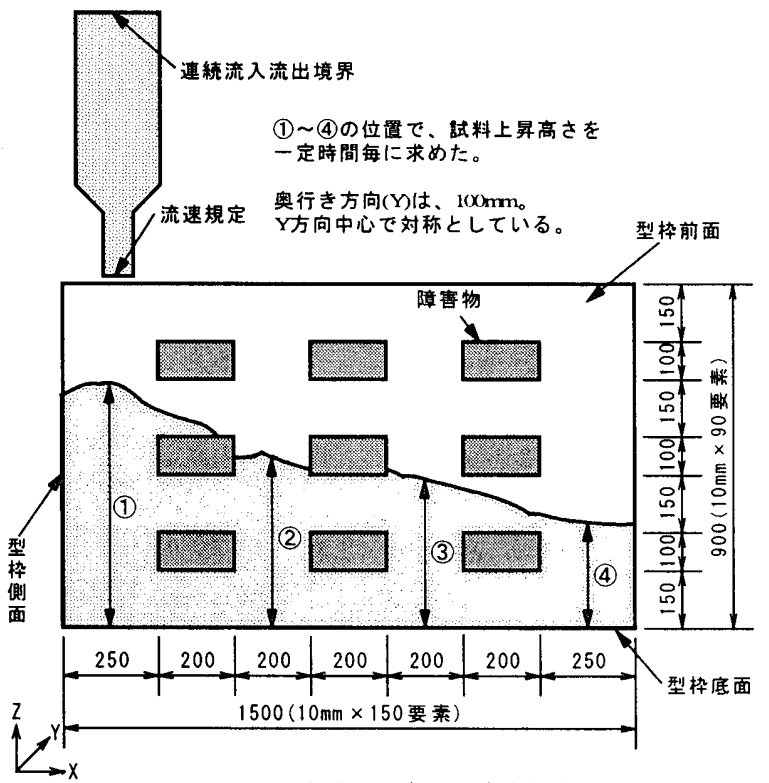

図 2 解析モデル（障害物粗）

表 1 境界部分の低減条件

\begin{tabular}{|c|c|}
\hline & 低减条件 \\
\hline ケース1 & 低減しない \\
\hline ケース2 & 寸べての境界部を $1 / 5$ \\
\hline ケース 3 & すぶての境界部を1/10 \\
\hline ケース4 & 型枠底面と障害物上面の境界部を $1 / 2$ その他を $1 / 5$ \\
\hline ケース 5 & 前後の型枠に接する境界部を1/10その他を1/1 \\
\hline
\end{tabular}
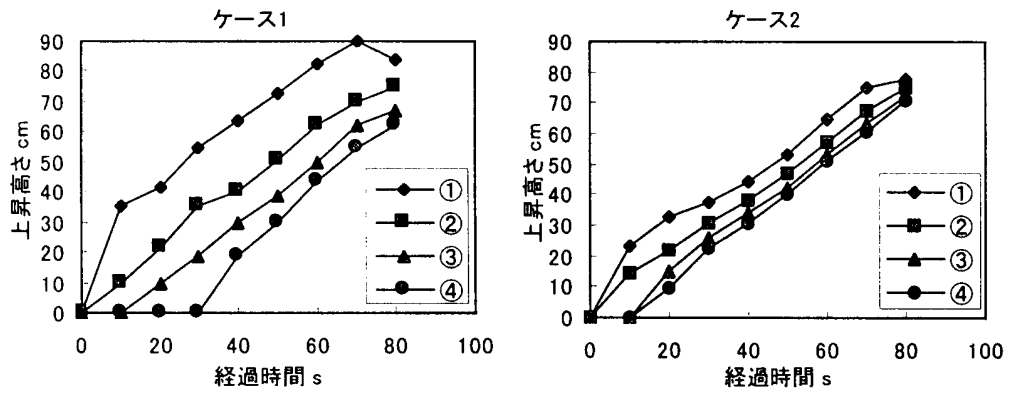

図 3 低減ケース 1 3 の試料上昇高さ
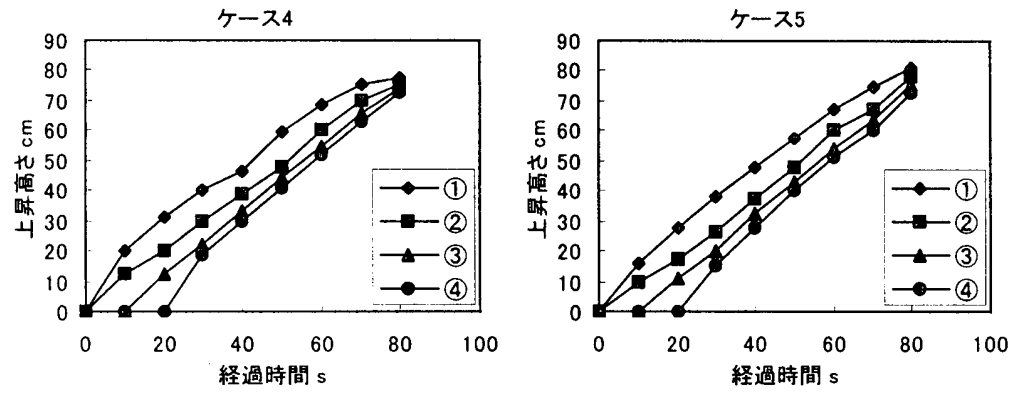

図 4 低減条件ケース 4.5 の試料上昇高さ
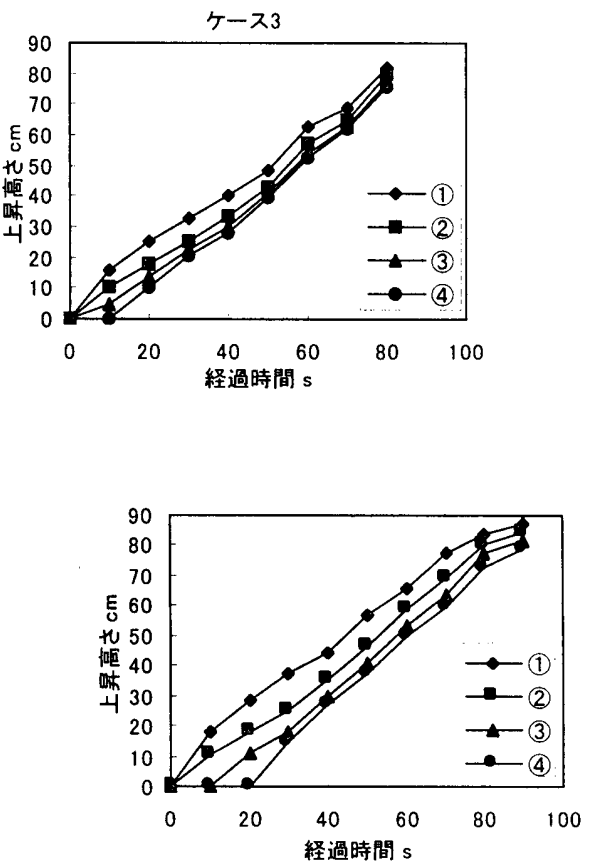

図 5 実験における試料上昇高さ 
型枠面より小さくしたケースについても解析した。垂直応力はコンク リートの高さ（深さ）により変化するため、打設の進行にともないせ 几断抵抗力も変化するものと考えられるが、計算が煩雑となるため今 回の解析では一定值とした。

な㧍、実験に用いたコンクリートは、粉体系の高流動コンクリート であり、スランプフロー69.1cm、50cm フロー到達時間5.6秒であった。

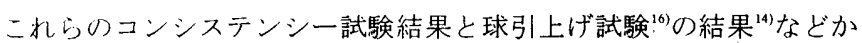
ら、解析に用いるレオロジ一定数は、降伏值 $\tau$ y を50Pa、塑性粘度 $\eta$ を100Pa・s と設定した。

\section{3 解析結果および考察}

境界部のレオロジ一定数の低減条件を変えて解析した結果を図3,4 に、試料上昇高さ（図2中の(1)（4)の高さ）と経過時間の関係として 示寸。また、図5に実験で得られた試料上昇高さを示す。図中で、同 時刻における各測点間の高さの差は、流動中の勾配を示し、同時刻に おける(1)と(4)の高さの差は全体的な勾配を示寸。

ケース1では、各測点間および全体の流動勾配とも、すべての時刻 において非常に大きい。先に述べたように、壁状の構造物などの 3 次 元解析を行うにあたっては、境界部分の見かけの粘性係数を低減する 必要があることがわかる。ケース2〜5においては、比較的実験結果を 良くシミュレートしている。ケース3では、各測点間および全体の流 動勾配とも、実験結果より小さめの值となっている。ケース2では、 全体的な勾配は実験結果を良くシミュレートするものであるが、(3)と (4)の20秒後や(1)と(2)の30〜50秒後などで一部異なる。ケース4,5にお いては、微細な部分に違いはあるが、各測点間および全体の流動勾配 上も非常に良く実験結果をシミュレートしている。

実験結果を良くシミュレートできたケースは、前後の型枠面に接す る境界部分を他の境界部分よりも大きく低減して計算したものであ った。ケース2,3が、ケース 4 よりも一致しなかった原因は、前後の型 枠面に接寸る境界部分以外の低減率が大きすぎたためと考えられる が、垂直応力を考慮した効果は顕著ではないことが予想できる。境界 部分にレオロジー定数の小さい層が存在する現象は、すべての境界で 等しく生じるものと考えられ、前後の型枠面だけを大きく低减する必 要があるとは考えにくい。そこで、壁近傍の流動現象を明確にするた め、流れを単純化したモデルによって検証を行った。

図6に解析モデルと解析結果を示す。矩形の管内の流入側に流速 (管 内の流速が壁型枠の解析時の流速.と同程度になる値に設定）を与え、 壁の厚み方向（Y方向の中心）で対称モデルとした。流体の接する境 界部はすべて non-slip 条件とし、境界部のレオロジ一定数の低減等は 行わず、重力加速度を Z 方向に与えた状態で、降伏值 $\tau$ y を50Pa、塑 性粘度 $\eta$ を $100 \mathrm{~Pa} \cdot \mathrm{s}$ として解析を行った。図中左側の境界部無処理の
結果において、XY 平面3.5秒にて境界部に接する面で流体が存在しな い部分が発生し6.0秒後でも依然として存在しない部分がある。XZ平 面の出力図によれば、重力により上面で付着や剥離が生じるが、下面 では流体の存在しない部分は発生しない。

本解析の VOF 法は、一般に自由表面の形状解析に用いられるもの である。流体体積率 VOF 值<1.0の部分については、周囲の VOF 值の 分布により流体表面を推定するが、運動方程式等の計算段階では、 VOF 値 $=1.0$ と同様に処理される。つまり、流体と境界との接触量等の 流体形状は考虑されておらず、VOF 值に応じた抵抗力が取り扱われ ている。このため、VOF 值<1.0の要素に扔いて、流体と境界が接触し ていない場合においても抵抗力が発生したり、接触面に相当する抵抗 力とは異なる抵抗力が作用する場合がある。材料の粘性が小さい場合
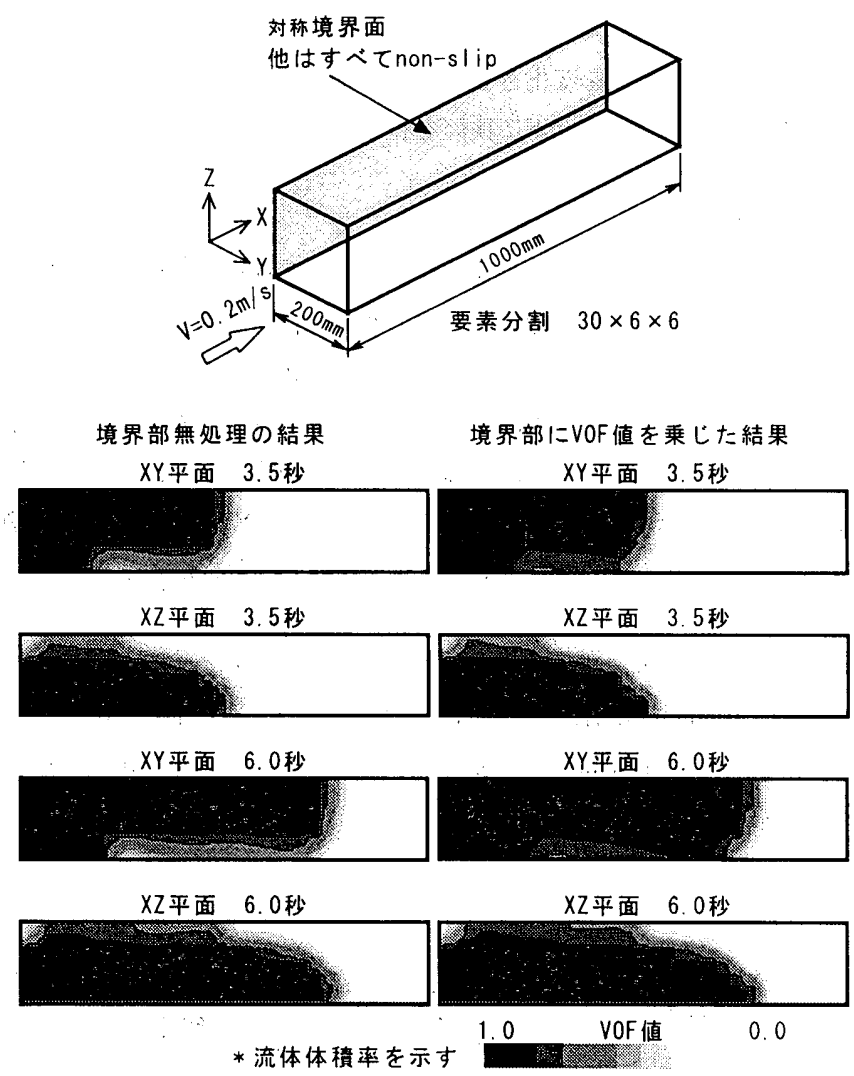

図 6 矩形管内の流動解析

表 2 VOF 值を乗じる解析条件

\begin{tabular}{c|c}
\hline & \multicolumn{1}{|c}{ 低減条件 } \\
\hline ケース6 & すべての要素のレオロジー定数にVOF值を乗ずる \\
\hdashline ケース7 & VOF值を乗じ、さらにすべての境界部を3/4に低減 \\
\hline ケース8 & VOF值を乗じ、さらにすべての境界部を1/2に低減 \\
\hline
\end{tabular}
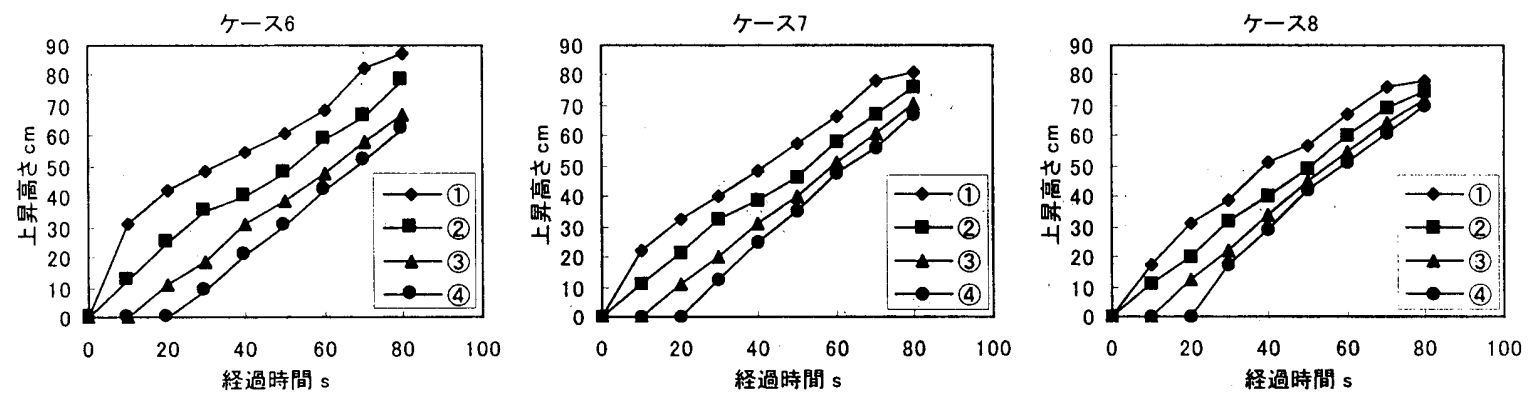

図 7 VOF 值を乗じた場合の試料上昇高さ 
は、これによる誤差は形状解析にほとんど影響しないが、粘性が大き い場合には無視できないものとなる。流動中の先端等の境界部分にお いては、ひずみ速度が大きく粘性も大きいため、過大な抵抗力が流れ を阻害する方向に作用する。このため、この部分で力の変化が不連続 になり、なめらかな流れにならないと考えられる。したがって、すべ ての要素のレオロジー定数に VOF 值を乗じることで、形状を考虑し た力を作用させる近似手法を試みた。その結果を図6の右側に示す。 境界部に特に処理を行わない結果と比較して、流体の存在しない不自 然な部分が発生せず、連続的でなめらかな流れが再現されている。壁 型枠のシミュレーションに掞いても同じ効果が得られるものと考え られる。

表2に示すように、VOF 值を乗ずる条件を変化させて解析を行った。 その結果を試料上昇高さと経過時間の関係として図7に示す。特に境 界部分の低減を行わずにVOF 值を乗じただけのケース6において、図 3 のケース1と比較して、流動勾配が大きく改善され、VOF 值を乗じ たことによる効果が確認できる。また、実験結果との比較によれば、 境界部分の低隇は必要であるものの、それほど大きく低減する必要は

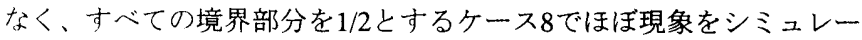
トすることができた。つまり、過大であった前後の型枠面による影響 が適正になったと考えられる。低減率1/2は、モルタルのレオロジー 定数がコンクリートの $1 / 10$ 程度 ${ }^{12}$ であること、境界部分の厚さが実際 にはごく薄いものであるのに対して、解析では1要素 $(10 \mathrm{~mm})$ として いること等を考慮すれば妥当な值と考えられる。境界部分の要素厚さ を変化させた場合には、低減率を変える必要が考えられるが、境界面 ひ举動を適切に評価するためと解析時間の面から低減率を $1 / 2$ とし、 境界部分の要素厚さを $10 \mathrm{~mm}$ 程度とすることが望ましい。

境界部分の取り扱い方法は、境界部分要素の見かけの粘性保数に VOF 值を乗ずるとともに、1/2に低減する条件に決定した。

続いて、フレッシュコンクリートのレオロジー定数と壁型枠中に配 置する障害物量をパラメータとした解析を行い、本境界部の低減方法 の適用性を確認する。

\section{4. 解析および実験的検証}

\section{1 解析項目}

解析に用いたレオロジー定数を表3に示す。標淮的な高流動コンク リートの調合（標準調合）に加えて、降伏值がやや大きい調合（降伏 值大）、塑性粘度がやや大きい調合（粘性大）についても解析を行っ た。降伏值大は高性能 $\mathrm{AE}$ 減水剂の添加量を減少させたものであり、 粘性大は増粘剤を添加し、高性能 $\mathrm{AE}$ 減水剂の添加量を増加させたも のである。それぞれ、スランプフローや50cm フロー到達時間と球引 上げ試験の結果"からレオロジ一定数を決定した。この他、障害物量 を増加させたもの（解析モデルを図8に示す）についても解析を行っ た。この場合も、コンクリートの打設方法および解析領域内（壁型枠 抽よびロート）の XY，YZ平面のメッシュ分割は、図2の解析モデル と同梯である。

\section{2 結果の考察}

図9〜14に、打設されたコンクリートが $0.01 ， 0.03 ， 0.06,0.09 \mathrm{~m}^{3}$ の 時点で流動中の形状を比較したもの、および、試料上昇高さ（図2,8 中の(1)〜(4)の高さ) と経過時間の関倸を解析条件毎に示す。図 9 の標 淮調合における障害物粗の試料上昇高さと経過時間の関係は、図7の
ケース8および図5に相当する。流動形状の図中の数值は、流動形状を 近似する直線（図中の細い線）の勾配を示し、上段が解析結果、下段 が実験結果である。

図9の標準調合における障害物粗の流動形状については、各段階と もに解析結果と実験結果の間に大きな違いは見られない。レオロジー 定数が適切で、流れのパターンを忠実にシミュレートすることができ たためと言える。図中に示した近似直線の勾配については解析結果が やや大きめの傾向を示寸が、その差は微少であった。

図10の標準調合におうる障害物密の流動形状については、体積 $0.01 \mathrm{~m}^{3}$ の時点で大きく異なる。これは、実験において、打設開始直後 にロート中で骨材が閉塞する現象が発生し、短時間ではあったがコン クリートが供給されなかったため、その間に高流動コンクリートひセ ルフレベリング性により、流動勾配が減少したことによる。これ以外 のケースではいずれも良くシミュレートできており、近似曲線の勾配 も体積 $0.01 \mathrm{~m}^{3}$ の場合を除いて良く一致している。近似曲線の勾配は、 標淮調合における障害物粗よりも大きくなっており、その傾向は打設 中期の体積0.03,0.06 $\mathrm{m}^{3}$ の時点において顕著である。試料上昇高さと経 過時間の関係においても、20〜70秒の範囲で、障害物密の方が(1)〜 (4)

表 3 解析に用いたレオロジー定数

\begin{tabular}{c|c|c}
\hline \multirow{2}{*}{} & \multicolumn{2}{|c}{ レオロ } \\
\cline { 2 - 3 } & 降伏值 $\tau \mathrm{y}(\mathrm{Pa})$ & 塑性粘度 $\eta(\mathrm{Pa} \cdot \mathrm{s})$ \\
\hline 標隻調合 & 50 & 100 \\
\hline 降伏值大 & 100 & 100 \\
\hline 粘性大 & 50 & 200 \\
\hline
\end{tabular}

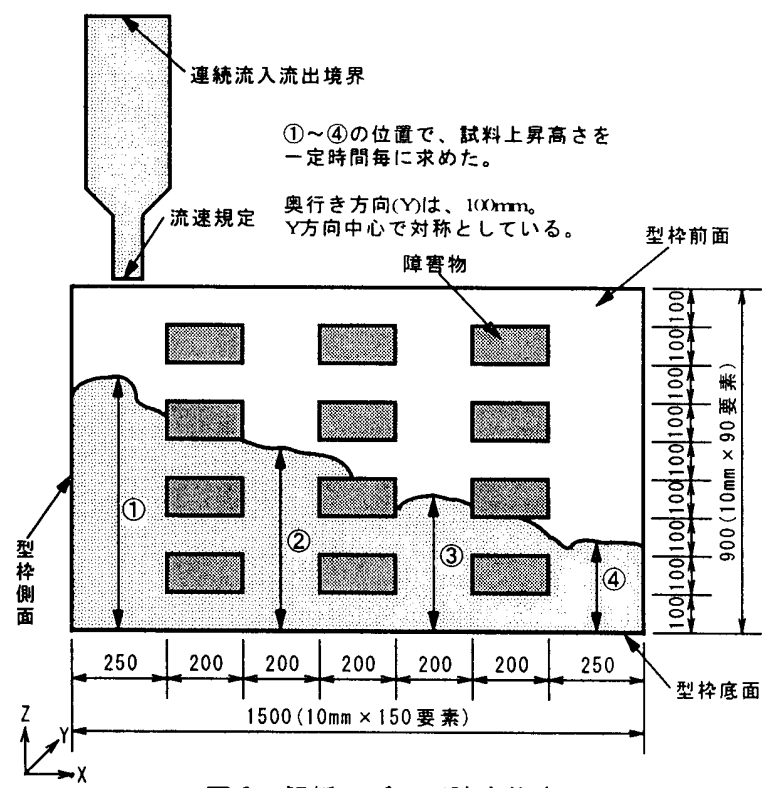

図 8 解析モデル (障害物密)

流動形状

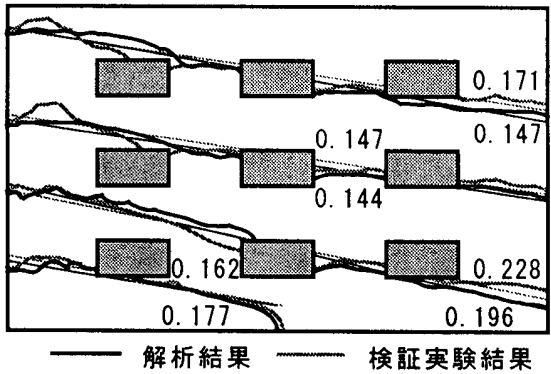

図 9 標準調合における障害物粗の流動形状 

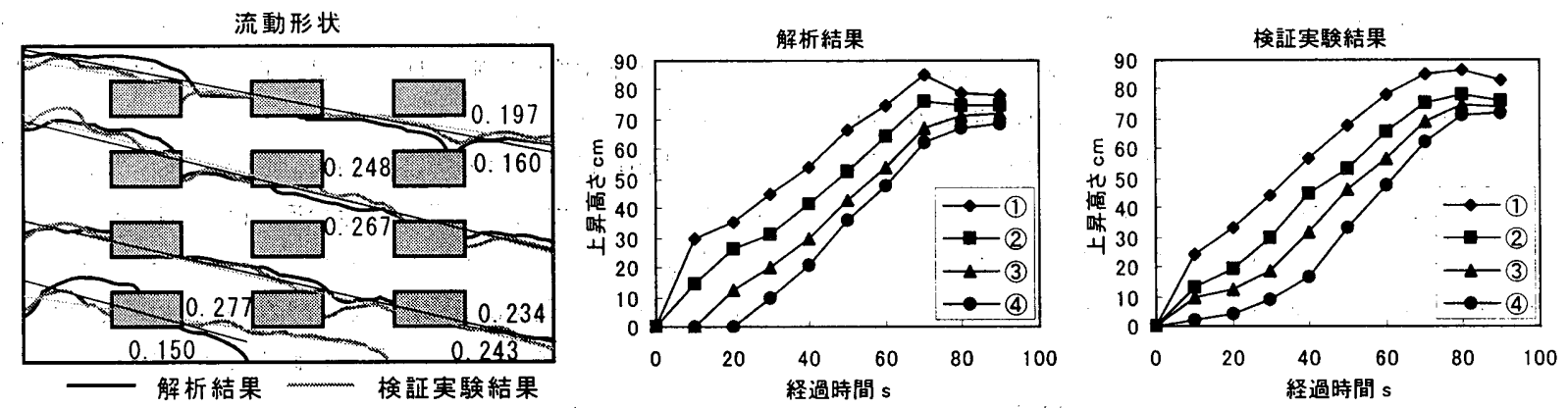

図 10 標準調合における障害物密の解析結果と実験結果の比較
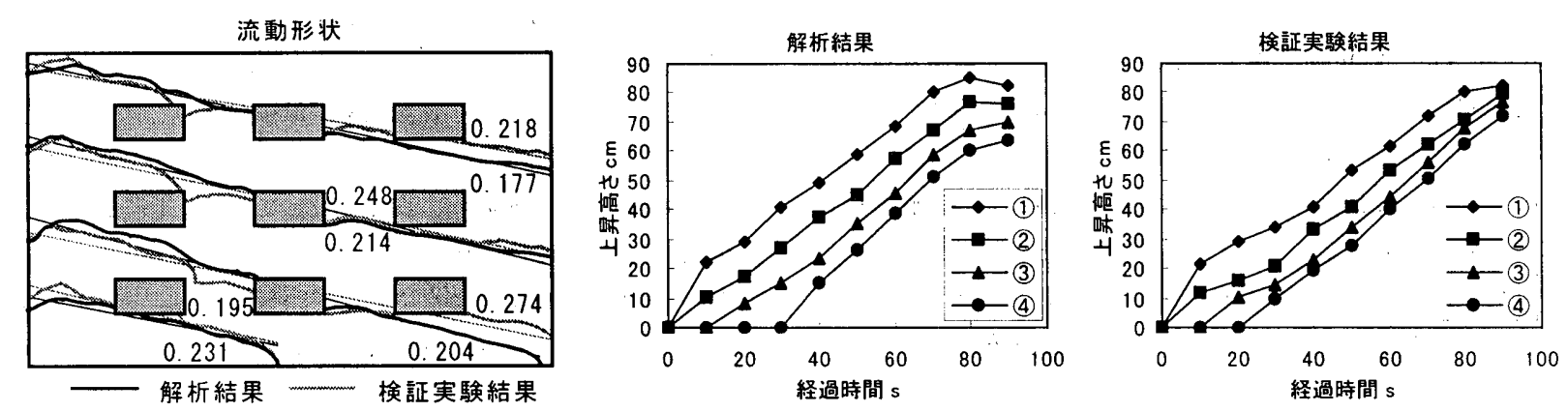

図 11 降伏値大における障害物粗の解析結果と実験結果の比較
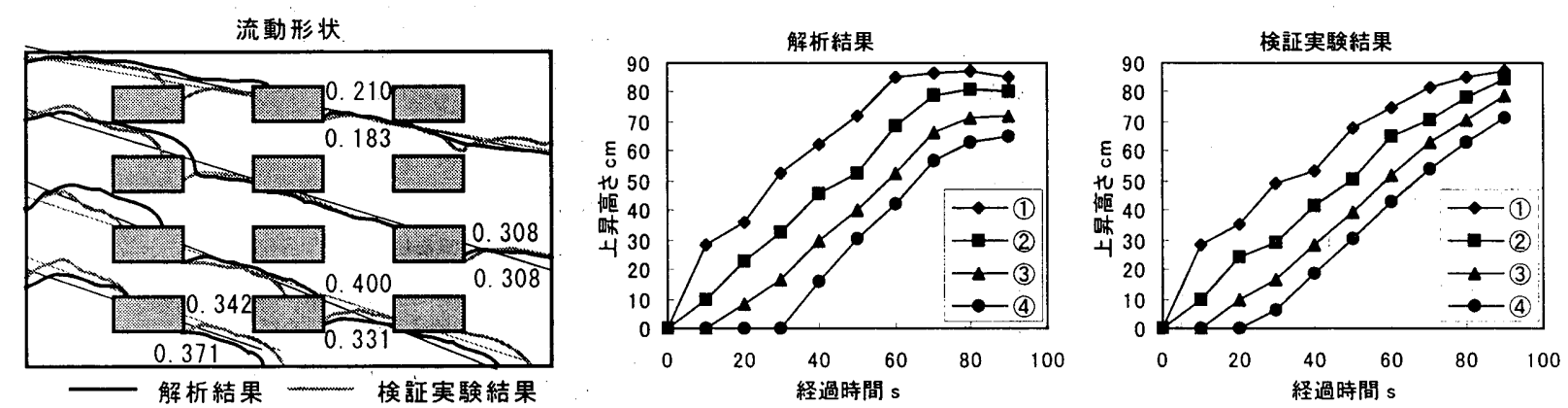

図 12 降伏値大における障害物密の解析結果と実験結果の比較
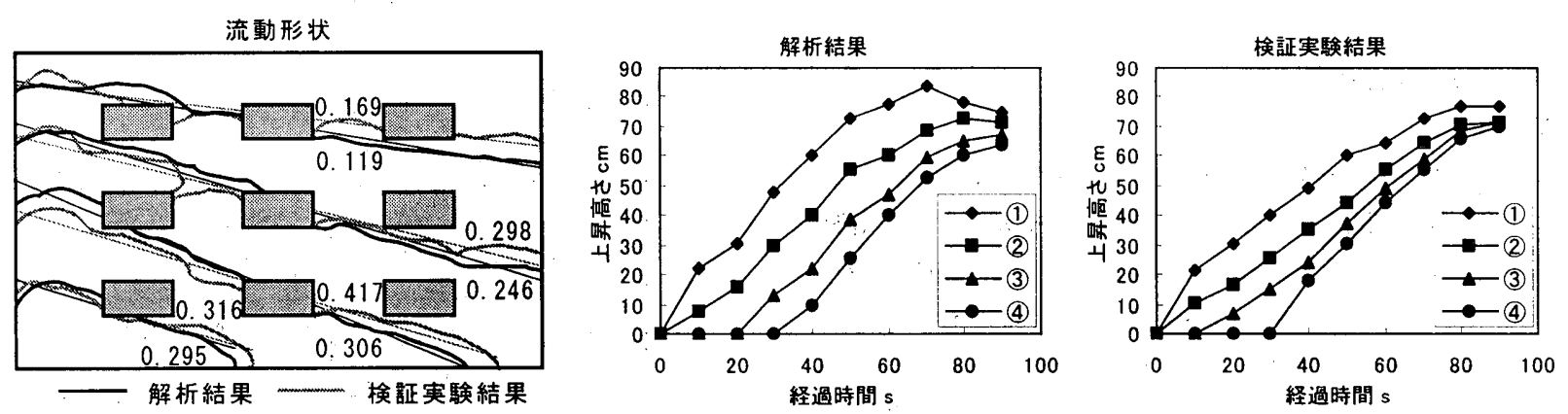

図 13 粘性大における障害物粗の解析結果と実験結果の比較
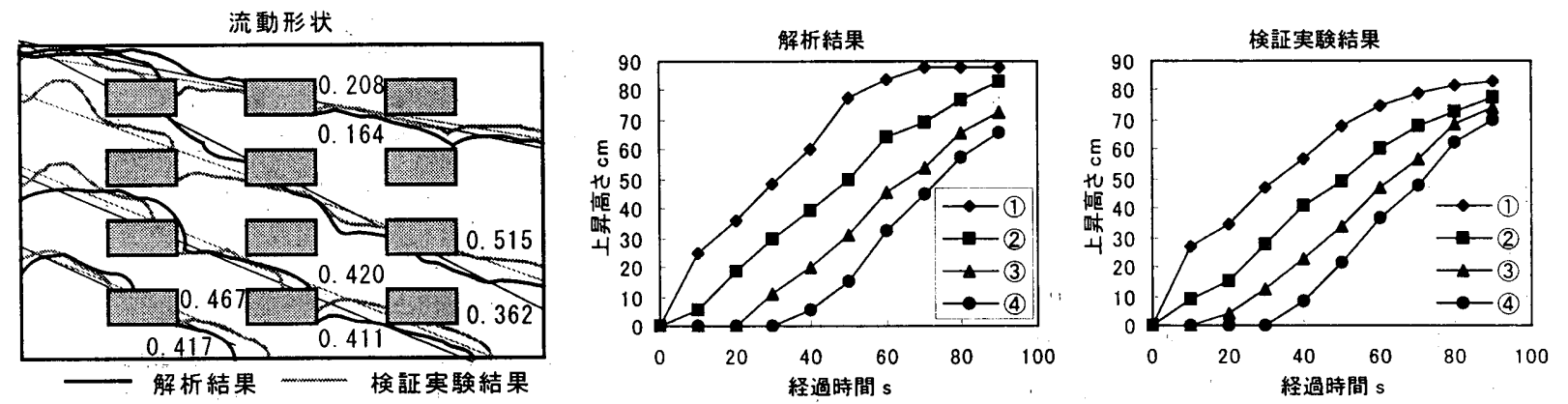

図 14 粘性大における障害物密の解析結果と実験結果の比較 
の高さの差が大きく、流動勾配が急であることがわかる。また、流動 が停止するときの勾配については、障害物量による差は顕著ではない。 障害物量が増加することは障害物間の間隙が減少することであり、障 害物の間隙比の現象が見かけ上の降伏値および塑性粘度の増加にな るとの既往の研究結果"吼に一致している。試料上昇高さと経過時間 の関係も、閉塞した区間においては実験結果と異なるものの、その他 注く一致している。

図11の降伏值大、障害物粗の流動形状については、 $0.03 \mathrm{~m}^{3}$ の時点で いくぶん形状が異なるが、その他の形状は一致している。近似直線の 抅配については、解析結果の方が大きめになる傾向が現れている。試 料上昇高さと経過時間の関係において、解析結果は全般に(1)〜(4)の高 さひ差が大きく、流動勾配が急になり、流動が停止した後に残留する 勾配についても大きくなっている。同じ障害物量の型枠においては、 降伏值の增加は、全般の流動勾配上昇に作用するとともに、流動が停 止するときの形状にも大きな影響を与えるものと考えられ、解析にお いて顕著にその影響が現れている。解析に用いた降伏值，塑性粘度は、 球引上げ試験結果によって求めた。フレッシュコンクリートのレオロ ジ一定数は、測定方法掞よび換算方法によって測定值に大きな差異が みられるのが現状であり、本解析で用いた值も誤差を含む可能性が考 えられる。たとえば、解析で用いる降伏值が本来の値より高く設定さ れていた場合、最終的な勾配が大きくなり、流動中の勾配にも影響を 与える。本流動シミュレーションシステムをより完全なものとするた めには、レオロジ一定数測定の方法などの検討も必要である。

図120降伏値大、障害物密において近似直線の勾配が大きくなる傾 向が見られるが、流動形状は比較的良くシミュレートされている。試 料上昇高さと経過時間の関倸においては、50〜60秒程度までの解析結 果上実験結果の差は小さいが、その後差が大きくなる。解析結果の最 終勾配が大きいの仕、解析で用いた降伏值が大きめであった可能性が 女り、流動中期の差が顕著でないことより、障害物量増加による塑性 粘度の見かけ上の増加の方が、流動勾配に与える影響が顕著である。

図130粘性大、障害物粗においては、近似直線の勾配が大きくなる 傾向が或分見られるものの、流動形状は比較的良くシミュレートされ ている。試料上昇高さと経過時間の関倸においては、40～50秒程度ま での解析結果と実験結果の差は小さいが、その後差が大きくなる。特 に50秒以降で(1)の上昇量が実験結果と異なっている。時間の経過とと もに(1)高さが上昇して、投入位置（ロート先端）との距離が小さく なると、解析においては塑性粘度が大きいためか、投入口から型枠中 までコンクリートが連続してしまうのに対し、実験ではこのような現 象は見られない。解析では、連続になるため上部からも流れに対する 拘束を受け、(1)の試料上昇高さが大きくなる。これは、本解析例の特 有の位置関係による現象之考えられる。

図140粘性大、障害物密においても、近似直線の勾配が大きくなる 傾向が見られ、流動形状については $0.06 \mathrm{~m}^{3} の$ 時点で異なっている。試 料上昇高さと経過時間の関係においても、粘性大、障害物粗の場合と 同様に、50秒以降で(1)上昇量が実験結果と異なっている。障害物量

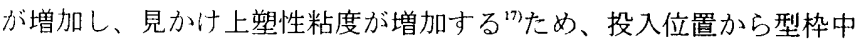
までコンクリートが連続する現象の影響が顕著になるものと考えら れる。試料上昇高さと経過時間の関係においては、(1)以外では、比較 的良く一致している。実験において、塑性粘度の増加は、主に流動途 中ひ勾配在增加させるものであり、停止するときの形状に与える影響 は小さいことが加かった。また、解析結果も同様の傾向を示した。
全般的にみて、一部にレオロジ一定数の設定やコンクリート投入部 の解析上の取り扱いに起因するとみられる誤差が生じたが、これらは 顕著ではなく、全般的に良好なシミュレーション結果が得られたと思 われる。

\section{5. まとめ}

本研究では、障害物を持つ壁状型枠を対象としたフレッシュコンク リートの3次元流動シミュレーションを行った。標準的な流動性能を 持つ高流動コンクリートを用いた解析と、同様の条件で実施した実験 の結果を比較することによって、境界部分の取り扱い方法について検 討した。また、フレッシュコンクリートのレオロジー定数と壁型枠中 に配置する障害物量をパラメータとした解析および実験を行い、結果 を比較・検討した。本研究によって得られた知見は、以下のとおりで あった。

1)境界部分の取り扱いについては、3次元解析において、す心゙ての要 素のレオロジ一定数に VOF 值（流体体積率）を乗ずるとともに、 境界部分ではその值を $1 / 2$ に低減する方法を提案した。

2)本低減方法を用いて、レオロジー定数と壁型枠中に配置する障害物 量をパラメータとした解析を行った結果、解析結果と実験結果の違 いは顕著なものでなく、実現象を充分にシミュレートすることがで きた。

3)調合によらず障害物量が増加することで流動勾配が增加し、見かけ 上塑性粘度が增大する実現象を解析においてもシミュレートする ことができた。

4)降伏值の増加は全般の流動勾配上昇に作用寸るのに対し、塑性粘度 の増加は主に流動途中の勾配を増加させるという実現象を解析に おいてもシミュレートすることができた。

\section{引用文献}

1)村田次郎, 菊川浩治：まだ固まらないコンクリートのレオロジ一定 数測定法に関する一提案, 土木学会論文報告集, pp. 117〜126, 1979. 4.

2)吉野 公, 西林新蔵, 井上正一, 黒田 保: コンクリートのレオロ ジー定数に及ぼす使用材料の影響, コンクリート工学年次論文報告 集, Vol. 17, No. 1, pp. 581 586, 1995.6.

3)水口裕之, 河野 清: 平行板プラスとメータによるフレッシュコン クリートのレオロジー定数測定法に関する検討, フレッシュコンク リートの物性值の測定ならびに挙動に関するシンボジウム論文集, pp. $17 \sim 24,1983.3$.

4) 森 博嗣, 田中政史, 谷川恭雄 : フレッシュコンクリートのせん断 変形性質に関する実験的研究, 日本建築学会構造系論文報告集, No. 421, pp. $1 \sim 10,1991.3$.

5) 寺田謙一, 谷川恭雄, 森 博嗣, 黒川善幸, 三島直生, 若林信太朗 せん断ボックス試験に基づくモデル材料を用いたフレッシュコン クリートのレオロジー性質に関する研究，日本建築学会構造系論文 報告集，No. 511，pp. 17〜24，1998. 9 。

6) 森 博嗣, 谷川恭雄, 黒川善幸, 小村理恵 : フレッシュコンクリー トのスランピング挙動に関するレオロジー的考察, コンクリートの 製造システムに関するシンポジウム論文集, pp. 43〜 48, 1992.5 .

7)神田 亭, 青景平昌: 流動シミュレーションの実施工一の適用に関 する一考察, フレッシュコンクリートの物性とその施工への適用に 関するシンポジウム論文集，pp. 37〜 42，1986. 3.

8) 森 博嗣, 谷川恭雄: 粘塑性有限要素法によるフレッシュコンクリ 一トの流動解析, 日本建築学会構造系論文報告集, No. 374, pp. 1 $\sim 9,1987.4$

9)森 博嗣, 谷川恭雄: フレッシュコンクリートの構成則に関寸る研 究, 日本建築学会構造系論文報告集, No. 396, pp. 9〜16, 1989. 2. 10) 㑣ソフトウエアクレイドル：3 次元熱流体解析ブログラム STREAM 11) 石黒和浩, 富谷潤一：フレッシュコンクリートの流動シミュレー 
ション（市販の流体解析コードの適用性），土木学会年次学術講演 概要集第5部, pp. 1028～1029， 1995.9.

12）青山晴洋，森博嗣，富谷潤一，石黒和浩，星野実，金井健一：障 害物を有する壁型枠への高流動コンクリートの打設実験（その1 調 合と基本性質），日本建築学会大会学術講演梗概集（関東），A-1， pp. $741 \sim 742,1997.9$.

13）石黒和浩, 森博嗣, 富谷潤一, 牧保峯, 齊藤和秀, 荒島猛: 障害 物を有する壁型枠への高流動コンクリートの打設実験（その2 壁 型枠打設扩よび粗骨材分布の均一性)，日本建築学会大会学術講演 梗概集（関東），A-1，pp. 743～744，1997.9.

14）石黒和浩, 森博嗣, 富谷潤一：障害物を有する壁型枠の2次元流動 シミュレーション，士木学会年次学術講演概要集第5部, pp. 378 379, 1998. 10.

15)石黒和浩, 森博嗣, 富谷潤一：フレッシュコンクリートの流動シ ミュレーション（その1 障害物を有する壁型枠），日本建築学会 大会学術講演梗概集（九州），A-1，pp. 989～990， 1998.9.

16) 土木学会 : フレッシュコンクリートの物性とその施エへの適用に 関寸るシンポジウム論文集，pp. 190～192，1997.9.

17）野口貴文, 友澤史紀, 吳 相均: 高流動コンクリートの間隙通過 性に関するレオロジー的考察，コンクリート工学年次論文報告集， Vol. 17, No. 1, pp. 23 28, 1995. 6 .

(2000年 3 月 9 日原稿受理， 2000 年 8 月 2 日採用決定 